\title{
A transmissão da fé na nova arquitetura da comunicação contemporânea
}

\author{
Handing on faith in the new architecture of contemporary communication
}

Joana Terezinha Puntel*

\begin{abstract}
Resumo
Evangelização no contexto da sociedade contemporânea, transmissão da fé, nova arquitetura da comunicação constituem os eixos centrais deste artigo. Estes eixos encontram-se interligados e giram como engrenagens necessárias para a transmissão da fé, hoje. Sociedade com um cenário marcado por inéditas experiências no campo da cultura digital, encontra-se um "novo sujeito" que se move dentro de uma nova arquitetura da comunicação. A modalidade da transmissão da mensagem altera-se de unilinear para novas formas de interação. No processo comunicativo da cultura digital, a transmissão unilinear (ou unidirecional) é substituída por aquela reticular, interativa e colaborativa (network). O estudo aborda a convergência e continuidade do magistério da Igreja sobre a evangelização e sua necessária abertura para o diálogo entre fé e cultura, a partir do Concílio Vaticano II. Considera a necessidade de repensar as modalidades existentes para a transmissão da fé. Atitude que requer coragem de pensar de modo mais profundo a relação entre fé, a vida da Igreja e as transformações que vivemos hoje. Na cultura digital, cresce e se alarga uma nova percepção e compreensão da fé. Na era digital novas linguagens desafiam paradigmas tradicionais e nos impelem para uma mudança de mentalidade e de prática pastoral.
\end{abstract}

Palavras-chave: Evangelização; Cultura digital; Diálogo; Fé; Linguagem

\begin{abstract}
Evangelization in the present contemporary context, transmission of faith, and the new architecture of communication are this article's central axes. Just as interconnected cogwheels, they need to function together to hand on faith appropriately in today's world. Our society, marked by unprecedented experiences in the field of digital culture, gave rise to a "new person", who lives and relates within a new architecture of communication altogether. In the communicative process of digital culture, the modality of communication has changed from a unilinear mode of transmission to networked, interactive, collaborative forms of interaction. Based on the teachings of the Second Vatican Council, and in an effort to rethink the present modalities of faith transmission, this study concerns both the convergence and continuity of the Magisterium of the Church on evangelization and the urgency for her to engage in a dialogue between faith and culture. This requires an attitude of courage to consider more deeply the relation between faith, Church life, and the current transformations as experienced today. For in the digital culture, a new perception and understanding of faith has grown and developed. New languages have challenged conventional paradigms and prompted us into a change of mentality and pastoral practice.
\end{abstract}

Keywords: Evangelization. Digital Culture. Dialogue. Faith. Language

\footnotetext{
Artigo recebido em 21 de dezembro de 2016 e aprovado em 29 de junho de 2017.

* Doutora em Ciências da Comunicação pela Universidade de São Paulo (1996) e pela Simon Fraser University (1991). Mestrado em Comunicação Social pela Universidade Metodista de São Paulo (1985) e graduação em Jornalismo pela Faculdade de Comunicação Social Casper Líbero (1975). Atua como docente no Programa de pós-graduação em Teologia da Pontifícia Universidade Católica do Rio Grande do Sul; e no curso de Especialização Cultura e Meios de Comunicação do SEPAC que se realiza em convênio com a PUCSP/COGEAE. É membro da INTERCOM. País de Origem: Brasil. E-mail: joana.puntel@gmail.com
}

Horizonte, Belo Horizonte, v. 15, n. 46, p. 486-509, abr./jun. 2017 - ISSN 2175-5841 


\section{Introdução}

Abordar a pertinência do tema Diálogo entre fé e cultura na evangelização do mundo de hoje implica numa tarefa que vai de uma pastoral aparentemente corriqueira à exigência de transformação de mentalidades e modalidades que ultrapassam o analisar superficialmente a "nova evangelização" e, por outro lado, o contexto histórico sóciocultural contemporâneo. Vive-se de forma progressiva, e até desconcertante, em uma sociedade complexa, de século 21. Complexidade que traz no seu bojo não só a mudança de paradigmas, mas novos paradigmas seja no campo das ciências, das novas sociabilidades que se re-configuram, no desenvolvimento acelerado das novas tecnologias da comunicação, mudança nos parâmetros na educação, enfim, nas novas realidades vividas pelas comunidades humanas, nas migrações contínuas e reações de violência e de políticas comprometidas com o mercado e não com o ser humano, bem como, situações novas de pluralismo religioso. Enfim, temos um "novo sujeito" ou um novo antropológico, com quem nos relacionarmos.

Nessa conjuntura, apresenta-se fortemente a problemática da transmissão da fé, como uma das questões centrais que emerge como desafio na dimensão da teologia. A percepção mais relevante da crise da transmissão da fé foi o cerne da reflexão realizada pelo Sínodo dos Bispos, em Roma (7 a 28 de outubro 2012) sobre "A nova evangelização para a transmissão da fé cristã". Os participantes buscaram aprofundar o significado teológico e pastoral da nova evangelização, perceber, conhecer e incentivar possíveis iniciativas ligadas à nova evangelização já em curso, estudar e favorecer a utilização das formas de comunicação modernas como instrumentos de evangelização, e promover o uso do Catecismo da Igreja Católica, como formulação essencial e completa do conteúdo da fé para os homens de nosso tempo (SUESS, 2012).

Importante considerar que na problemática ou crise da transmissão da fé, acentua-se o fato de que a proclamação do querigma salvífico, centrado nas palavras e vida de Jesus Cristo jamais envelhece, permanece sempre o mesmo. 
Mas são as modalidades da transmissão da fé que devem seguir a exigência de uma nova relação do homem contemporâneo com a fé. Enquanto o conteúdo da verdade permanece o mesmo no decorrer dos tempos, mudam as percepções do mesmo. A fé é sempre a fé, mas a percepção da mesma passa por transformações e diversas interpretações ao longo da história com novos sujeitos, novos contextos socioculturais, onde existem homens e mulheres que vivem numa determinada época histórica, com anseios, carências, angústias, busca de sentido diversificados de outras épocas. Há uma realidade concreta, hoje, onde é preciso transmitir a fé. Entretanto, o como transmitir a fé, evoca e provoca uma nova modalidade de evangelização (FRANÇA MIRANDA, 2015).

Este artigo não analisa a variedade de implicações que se apresentam hoje para a evangelização, quer no seu aspecto de revelação da fé, de doutrina e suas implicações mais diretas com o conteúdo teológico da mensagem de Jesus Cristo. Mas ocupa-se da transmissão da mensagem, entendendo “transmissão" como a exigência de novas modalidades, ou linguagens de comunicação que possibilitem as pessoas que vivem nesta época histórica sociocultural compreender e viver a fé. Partindo do pressuposto de que a missão essencial da Igreja é evangelizar e como diz a Evangelii Nuntiandi “evangelizar é a sua mais profunda identidade” (EN 14), a Igreja não poderia falhar na inculturação necessária para alcançar o homem e as mulheres do nosso tempo, pois a Igreja nasce da ação evangelizadora de Jesus. Mudam as formas, mas não muda o conteúdo, permanecem as exigências de anunciar a salvação, a libertação (EN 9). E este anunciar a Boa Nova se torna imperativo, também pelo fato de que a evangelização deve levar em consideração as mudanças histórico-culturais, que se compõem com novas maneiras de pensar, de aprender, de ensinar, enfim, de vivenciar a fé. Aí, entram, por exemplo, as linguagens. ${ }^{1}$ Vivemos um novo socius. O recorte deste artigo, portanto, foca sobre o diálogo entre fé e cultura, no que diz respeito à mudança de paradigmas da comunicação e sua incidência nos métodos pastorais, visto vivermos em uma nova

\footnotetext{
${ }^{1}$ Linguagem é entendida aqui como toda e qualquer expressão de comunicação seja verbal, não verbal, mediada pela técnica, digital.
} 
ambiência $^{2}$ de cultura midiática, onde se realiza a evangelização, no mundo contemporâneo.

\section{Convergência e "fusão de horizontes" ${ }^{3}$ no caminho de abertura}

Que a Igreja se inserisse na história e fosse a Igreja de todos os povos com um anúncio do Reino de Deus renovado e ao encontro das necessidades do homem contemporâneo, foi o desejo de João XXIII, já no discurso de abertura do Concíio Vaticano II (11/10/1962) quando usou as palavras-chave diálogo e aggiornamento. $\mathrm{Na}$ afirmação do "padre conciliar" Aloisio Cardeal Lorscheider (2004, p.6), o objetivo do Vaticano II era, na opinião de João XXIII, a evangelização do mundo atual: "Como evangelizar o mundo de hoje? A intenção do Concílio era eminentemente pastoral: reler e interpretar o Evangelho para os nossos dias (...), abrir-se ao novo que estava sendo gestado”. O Concílio Vaticano II, já reconhecido como o maior evento eclesial do século XX, levou João Paulo II a escrever "sinto ainda mais intensamente o dever de indicar o Concílio como a grande graça que beneficiou a Igreja no século XX: nele se encontra uma bússola segura para nos orientar no caminho do século que começa" (VALENTINI, 2011). De fato, o Concílio Vaticano II tratou de mexer com a mentalidade, com novas leituras, com novos paradigmas e, assim, com novas narrativas para a evangelização.

\subsection{Gaudium et Spes: visão nova da relação entre Igreja e sociedade}

E é com um dos seus documentos, a Constituição pastoral Gaudium et Spes, que a Igreja começa a ter uma visão "completamente nova da relação entre Igreja e mundo, relação de aproximação e não de distanciamento" (SOUZA, 2004, p. 64). Tal visão é um marco fundamental no aggiornamento que a Igreja se propusera. Ela se situa no mundo, compreendendo o momento de secularização em que a religião não é levada em conta, está decentralizada. Adota, então, uma postura de

2 O termo “ambiência” foi usado por mim já em 2008, no livro Cultura midiática e Igreja: uma nova ambiência (PUNTEL, 2008).
${ }^{3}$ A expressão “fusão de horizontes" encontra-se em Christoph Theobald (2016). 
diálogo para cumprir sua missão de "salvar a pessoa humana, de edificar a sociedade humana” (GS 3). Surge aí uma exigência: escutar o mundo, compreender os seus problemas, os seus caminhos de esperança e aí anunciar ao mundo a palavra do Evangelho, que é Cristo. Dessa mudança de postura, decorre que a pedagogia de evangelização e de ação pastoral não deveria ser de imposição, mas de um diálogo com toda a sociedade humana, em especial com a ciência, para contribuir principalmente na dignidade da pessoa humana em sua integralidade. E mesmo após 50 anos de sua publicação, o diagnóstico feito pela Gaudium et Spes continua válido para nossos dias, pois embora as mudanças se sucedem, o eixo de abertura para o mundo moderno, mediante o diálogo é aquele que permanece como eixo principal para realizar a evangelização.

Assim que, entre as preocupações apontadas na Gaudium et Spes, verificamos uma preocupação dialógica: "a Gaudium et Spes passa das condenações anteriores à disposição para dialogar” (LOPES, 2011, p.14). O diálogo passa, então, por uma atitude de abertura das “janelas do Vaticano aos novos ares”. E diante do que a Igreja vê e analisa, nascem as mais diversas perguntas baseadas no "como" entrar em diálogo, por exemplo com a ciência e o pensamento contemporâneo; o reconhecimento dos avanços e limites do progresso tecnológico; como realizar a evangelização diante dos problemas e desafios. Era necessário rever o processo de evangelização, pois, este deveria passar por uma profunda inculturação (LOPES, 2011). A Gaudium et Spes revela também uma preocupação antropológica, a pessoa humana é colocada no centro de suas atenções. A centralidade cristológica, reafirmando uma confissão a Cristo; a centralidade eclesiológica apresentando uma nova eclesiologia; a centralidade pastoral-comunitária apresentando uma nova dimensão de pastoralidade em meio aos desafios contemporâneos; a centralidade profética, no agir como cristãos nos campos econômico, político, social e cultural (LOPES, 2011). 


\subsection{Evangelii Nuntiandi - nos passos da Gaudium et Spes}

$\mathrm{Na}$ dinamicidade empreendida pelo Concílio Vaticano II e diante do vertiginoso desenvolvimento técnico e científico e velocidade de transformações que atingem o ser humano na sociedade contemporânea, a Igreja volta a se perguntar "o que é evangelizar?” e "como" evangelizar na sociedade em mudança. Perguntas essas que constituíram o fio condutor da III Assembleia Geral do Sínodo dos Bispos, dedicado à evangelização, em 1974. Os Padres sinodais confiaram a Paulo VI os resultados dos trabalhos sinodais "declarando que esperavam do Papa um impulso novo, capaz de suscitar, numa Igreja ainda mais arraigada na força e na potência imorredouras do Pentecostes, tempos novos de evangelização". (PAULO VI, 1974). Como fruto dos trabalhos do sínodo, nasceu, então, a Exortação Apostólica Evangelii Nuntiandi, promulgada por Paulo VI no dia 8 de dezembro de 1975, no décimo aniversário da Gaudium et Spes.

O documento é uma reflexão sobre a evangelização, a partir das riquezas do Sínodo. A Igreja se examina a si mesma colocando-se perguntas que Paulo VI relembra na Introdução do documento:

O que é que é feito, em nossos dias, daquela energia escondida da Boa Nova, suscetível de impressionar profundamente a consciência dos homens? Até que ponto e como é que essa força evangélica está em condições de transformar verdadeiramente o homem deste nosso século? Quais os métodos que hão de ser seguidos para proclamar o Evangelho de modo a que a sua potência possa ser eficaz? (...) Após o Concílio e graças ao Concílio, que foi para ela uma hora de Deus nesta viragem da história, encontrar-se-á a Igreja mais apta para anunciar o Evangelho e para o inserir no coração dos homens, com convicção, liberdade de espírito e eficácia? (EN n.4).

A Evangelii Nuntiandi passa a refletir sobre elementos essenciais da evangelização e da identidade da Igreja, reafirmando que a apresentação da mensagem evangélica não é para a Igreja uma contribuição facultativa, mas um dever que lhe incumbe, por mandato do Senhor Jesus. E as palavras finais da Assembleia de 1974 foram luminosas ao dizer "Nós queremos confirmar uma vez mais ainda que a tarefa de evangelizar todos os homens constitui a missão essencial 
da Igreja”. Evangelizar constitui, de fato a graça e a vocação própria da Igreja, a sua mais profunda identidade. Ela existe para Evangelizar (EN n. 14).

Na certeza de ter esclarecido, mais uma vez, a sua identidade ("ela existe para evangelizar”), a Igreja reflete, agora, sobre a pergunta que constitui a raiz, o fundamento de toda a ação da Igreja: o que é evangelizar? Pergunta e respostas que parecem óbvias, mas que trazem a necessidade de serem frequentemente revisitas, nos complexos contestos e diversidades de pensamentos e idealogias que enfrentamos hoje: "Evangelizar é levar a Boa Nova a todas as parcelas da humanidade, em qualquer meio e latitude" (EN n.18). O núcleo central e ponto de partida para a evangelização é sempre Jesus Cristo, que, como evangelizador, anuncia, em primeiro lugar um reino, o Reino de Deus. Portanto, o Reino de Deus e a salvação são palavras-chave da evangelização de Jesus Cristo (EN n.10). O convite é que transforme as pessoas a partir de dentro e assim, a própria humanidade tonar-se-à nova. "No entanto não haverá humanidade nova, se não houver em primeiro lugar homens novos, pela novidade do batismo e da vida segundo o Evangelho. A finalidade da evangelização, portanto, é precisamente esta mudança interior" (EN n. 18).

A Evangelii Nuntiandi não trata especificamente de assuntos sociais, mas apresenta o Evangelho como libertação e expressa que,

para a Igreja, não se trata tanto de pregar o Evangelho a espaços geográficos cada vez mais vastos ou populações maiores em dimensões de massa, mas de chegar a atingir e como que a modificar pela força do Evangelho os critérios de julgar, os valores que contam, os centros de interesse, as linhas de pensamento, as fontes ispiradoras e os modelos de vida da humanidade, que se apresentam em contraste com a Palavra de Deus e com o desígnio da salvação (EN n.19).

A exigência é para que se evangelize não de forma superficial ou decorativa, como "aplicando um verniz, mas de maneira vital, em profundidade e isto até às raízes”. Evangelizar a cultura e as culturas do homem, a partir sempre da pessoa e fazendo continuamente apelo para as relações das pessoas entre si e com Deus (EN 
n.20). O documento deixa claro que embora o "Evangelho e a evangelização não se identificam com a cultura”, a mensagem precisa ser anunciada a pessoas que vivem determinadas culturas e, por isso, serve-se de elementos da cultura e das culturas humanas. Daí que a exortação é enfática em afirmar que "a ruptura entre o Evangelho e a cultura é sem dúvida o drama da nossa época, como o foi também de outras épocas" (EN n.20).

\subsubsection{Como evangelizar}

Volta o eixo da Gaudium et Spes - diálogo e aggiornamento. O como evangelizar é uma pergunta que a Igreja deve fazer constantemente, porque as maneiras de realizar a evangelização variam frequentemente conforme as épocas, lugares, culturas e, por isso mesmo, apresentam desafios à capacidade de descobrir, conhecer, inculturar-se, escutar, perceber, dialogar, anunciar como Jesus que "não falava como que 'de fora', mas 'de dentro', a partir do seu povo; anunciava-lhe a palavra de Deus, toda a palavra de Deus, com coragem e sem compromissos; e no entanto adaptava-se à sua linguagem e mentalidade, encarnado como estava, na situação, a partir da qual falava”. (O'CONNOR, 1971, Communio et Progressio, n. 11). Portanto, é indispensável remodelar com ousadia, e com prudência e fidelidade ao conteúdo, os processos, para comunicar a mensagem evangélica às pessoas do nosso tempo, conclui a Evangelii Nuntiandi (n.40).

\subsection{Exortação Apostólica Evangelii Gaudium}

Nos passos da Gaudium et Spes e da Evangelii Nuntiandi, a Igreja volta a refletir sobre a evangelização no mundo contemporâneo na $13^{\mathrm{a}}$ Assembleia geral Ordinária do Sínodo dos Bispos com o tema "A nova evangelização para a transmissão da fé cristã", em outubro 2012. Como fruto dos trabalhos da Assembleia e com a visão lúcida e missionária do Papa Francisco, ele oferece à toda comunidade católica a Evangelii Gaudium, um documento que equivale a uma 
carta de princípios de Francisco, pois ele mesmo diz que "possui um significado programático e tem consequências importantes”. A esperança de Francisco é que haja uma retomada missionária, impregnada de avanços no caminho de "uma conversão pastoral e missionária, que não pode deixar as coisas como estão”. E citando o documento de Aparecida, diz que "neste momento, não nos serve uma «simples administração». É necessário um “estado permanente de missão», em todas as regiões da terra. (EG n.25).

Numa realidade de Igreja missionária que deve levar em conta a abertura e o diálogo com as pessoas de hoje, o Papa Francisco, na Evangelii Gaudium, expressa seu sonho para a Igreja ideal no sentido de uma opção missionária que transforme tudo: "para que os costumes, os estilos, os horários, a linguagem e toda a estrutura eclesial se tornem um canal proporcionado mais à evangelização do mundo atual que à auto-preservação" (EG n.27). Para isso, Francisco chama a atenção para situar a Igreja na história. Francisco sabe que documentos já não despertam interesse como em outros tempos e que caem logo no esquecimento, por isso ele afirma que diante das "enormes e velozes" mudanças culturais , é preciso "tentar expressar as verdades de sempre em uma linguagem que permita reconhecer a sua permanente novidade" (EG n.41).

Com objetivos explícitos de levar os cristãos a "uma nova etapa evangelizadora marcada pela alegria; e indicar caminhos da Igreja nos próximos anos” (EG n.1), Francisco levou em consideração sim os resultados do Sínodo, mas ousou pensar uma nova forma de ser Igreja hoje. E começa por dizer que nos cenários e desafios sempre novos da missão evangelizadora da Igreja, todos somos chamados a uma nova "saída" missionária. O convite é para "sair da própria comodidade e ter a coragem de alcançar todas as periferias que precisam da luz do Evangelho" (EG n.20). O documento revela a consciência de que Francisco sabe que não são poucos os desafios para a vivência da fé e sua transmissão no mundo atual. Para além de um mundo de relações globais e plurais, muitas são as questões inquietantes como a desigualdade, o individualismo, a violência, as mudanças 
climáticas, entre outras. Há uma casa comum, mas não espaço e oportunidade para todos.

Há, também um aspecto inovador, no documento, que é o processo dialogal, pois Francisco consultou várias pessoas, porque “não convém que o papa substitua os episcopados locais no discernimento de todas as problemáticas que sobressaem nos seus territórios. Neste sentido, sinto a necessidade de proceder a uma salutar 'descentralização”' (EG n.16). Além do aspecto dialogal Francisco afirma que o anúncio da fé, hoje, é comunicá-la em uma nova "linguagem parabólica” (n. 167- o Papa cita Bento XVI). E diz "é preciso ter a coragem de encontrar os novos sinais, os novos símbolos, uma nova carne para a transmissão da Palavra” (N; 167). Ele mesmo faz uso de novas parábolas e figuras de linguagem que ajudam a aprofundar a reflexão. A título de ilustração, alguns exemplos: "há cristãos que parecem ter escolhido viver uma Quaresma sem Páscoa" (n. 6); "Muitas vezes agimos como controladores da graça e não como facilitadores. Mas a Igreja não é uma alfândega; é a casa paterna, onde há lugar para todos com a sua vida fatigante” (n. 47);“A psicologia do túmulo (...) pouco a pouco transforma os cristãos em múmias de museu” (n. 83); "Uma das tentações mais sérias que sufoca o fervor e a ousadia é a sensação de derrota que nos transforma em pessimistas lamurientos e desencantados com cara de vinagre" (n. 85); "Deus nos livre de uma Igreja mundana sob vestes espirituais ou pastorais!” (n. 97).

Depois de enfatizar a transformação missionária da Igreja, a necessidade de uma saída para o mundo e a conversão da pastoral, Francisco enfrenta a realidade do mundo atual. $\mathrm{O}$ texto não se arroga nenhuma qualidade científica sociológica. "Não é função do Papa", observa ele, "oferecer uma análise detalhada e completa da realidade contemporânea". Toca-lhe animar "todas as comunidades a «uma capacidade sempre vigilante de estudar os sinais dos tempos" (EG n.51). No entanto, os pontos escolhidos para retratar a realidade revelam o coração do Papa e sua sensibilidade pastoral. Assinala o contraste entre os avanços do bemestar do mundo moderno e a maioria que vive precariamente o dia a dia. E na raiz 
está a economia da exclusão e da iniquidade que mata. "E muitas vezes, as estruturas sociais, políticas, econômicas acabam esmagando e diminuindo a possibilidade de um existir com dignidade” (THEOBALD, 2016).

Poderia-se, ainda enfatizar que na Evangelii Gaudium, nos passos da Gaudium et Spes e da Evangelii Nuntiandi, Francisco olha para Deus, para a Igreja e para a pastoral. Em relação a Deus, desenha-nos a face misericordiosa do Pai. Ao olhar para a Igreja, brotam profundos desejos de conversão naquilo que ela se afasta do projeto de Jesus: ser próxima do povo, anunciadora do amor e não voltada para si, para o seu lado puramente institucional. Com o olhar pastoral, pensa a evangelização, como saída, especialmente, em direção aos pobres e afastados da Igreja para anunciar-lhes o amor misericordioso de Deus, manifestado, sobretudo, na pessoa de Jesus Cristo e atualizado pela ação do Espírito no coração dos fiéis e de todos os seres humanos (LIBANIO, 2016).

\section{Caminhar na mudança cultural}

Os documentos Gaudium et Spes, enfatizando o diálogo e aggiornamento com o homem contemporâneo; bem como a Evangelii Nuntiandi, refletindo sobre a exigência de evangelizar não de forma superficial ou decorativa, mas "anunciar a mensagem a pessoas que vivem determinadas culturas e, por isso, [o anúncio] serve-se de elementos da cultura”, oferecem diretrizes explícitas para a Igreja evangelizar tomando em consideração o diálogo entre fé e cultura. Mais recentemente, em continuação e como fruto da reflexão do Sínodo sobre uma nova evangelização para a transmissão da fé, o papa Francisco, na Evangelii Gaudium, chama a atenção para uma nova forma de ser Igreja hoje, situando-se na história: "é preciso ter a coragem de encontrar os novos sinais, os novos símbolos, uma nova carne para a transmissão da Palavra". E, ainda, "tentar expressar as verdades de sempre em uma linguagem que permita reconhecer a sua permanente novidade” (EG n.41). Para isso o chamado para uma nova saída missionária. 
O mundo contemporâneo vive uma nova ambiência, na qual a transmissão da fé "entra em crise" por muitos fatores que se apresentam como desafios para uma mudança de mentalidade, de uso de linguagens, sobretudo pelas contínuas transformações da cultura midiática, onde se constata, não apenas as novas tecnologias em acelerado desenvolvimento das mídias digitais, mas um "novo sujeito", uma nova relação com a fé, uma nova percepção da fé e de Deus. Isto requer uma nova maneira de transmitir a fé. Constatar que há uma passagem na relação do ser humano com o sagrado, com as interações comunicacionais proporcionadas pelo ambiente digital é algo que se apresenta como "novos" horizontes desafiadores para a evangelização ao transmitir a fé num processo de midiatização digital da religião.

Já o papa Bento XVI, considerado o primeiro papa de uma era acentuadamente digital, compreendera esses "novos horizontes desafiadores" abordando a temática em várias mensagens para o Dia Mundial das Comunicações, incentivando a reflexão para um conhecimento e uma nova presença da Igreja no "continente digital"4. Nos atuais processos de comunicação que as novas mídias oferecem, ele afirma "Este é um dos caminhos onde a Igreja é chamada a exercer uma 'diaconia da cultura' no atual 'continente digital'”. Num esforço e reflexão progressiva, demonstrando conhecimento, abertura para a cultura contemporânea, e firmeza no ensinamento do magistério que é preciso realizar uma evangelização de diálogo entre fé e cultura, as mensagens de Bento XVI revelam o quanto a Igreja é solicitada a caminhar na mudança cultural e a "sair" da defasagem eclesial na maneira de transmitir a fé. Assim é que entre as suas mensagens, enfatiza-se a de 2013: "Redes Sociais: portais de verdade e de fé: novos espaços de evangelização". Bento XVI era ciente de que "a profunda transformação operada no campo das comunicações guia o fluxo de grandes mudanças culturais e sociais” (2011), onde os jovens habitam "um mundo digital que, entretanto, para nós, adultos, muitas vezes parece estranho" (2009). ${ }^{4}$ Expressão usada por Bento XVI (2010) em sua mensagem para o 440 Dia Mundial das Comunicações: O sacerdote e a pastoral no
mundo digital: os novos media ao serviço da Palavra.16/05/2010. 
Sobretudo os jovens estão a viver esta mudança da comunicação, com todas as ansiedades, as contradições e a criatividade própria de quantos se abrem com entusiasmo e curiosidade às novas experiências da vida. $\mathrm{O}$ envolvimento cada vez maior no público areópago digital dos chamados social network, leva a estabelecer novas formas de relação interpessoal, influi sobre a percepção de si próprio e por conseguinte, inevitavelmente, coloca a questão não só da justeza do próprio agir, mas também da autenticidade do próprio ser. (BENTO XVI, 2011)

O contexto das transformações provocadas pelas novas mídias (ou pósmassivas), e que chamamos de cultura digital ou cibercultura marcam a cultura contemporânea, especialmente com o surgimento da microinformática que vai dar o tom planetário, "que ganha uma dimensão mais radical com o surgimento das redes” (LEMOS, 2009, p. 136). É então essa cultura do telefone celular, dos computadores, das redes, dos micro-objetos digitais que funcionam a partir do processo eletrônico digital. Em outras palavras, a cibercultura seria a cultura contemporânea, onde os diversos dispositivos digitais já fazem parte da nossa realidade.

Importante observar que o que alterou substancialmente é a nossa relação com os objetos técnicos na atualidade, ou seja, "pela primeira vez, talvez, temos a dimensão técnica, o digital, colado à dimensão da comunicação". Por isso, a importância de considerar que se trata de tecnologias não apenas da transformação material e energética do mundo, mas elas permitem a transformação comunicativa, política, social e cultural. Pois "conseguimos transitar informações, bens simbólicos, não materiais, de uma maneira inédita na história da humanidade" (LEMOS, 2009, p. 136).

No mundo digital, de modo muito original e em ritmo cada vez mais acelerado, a internet irrompeu oferecendo um mundo novo de informações, com possibilidades inéditas de acolhida de mensagens e de acesso a informações em todos os setores da vida e da cultura. E, mais ainda, a internet viabilizou a intervenção, a participação ativa e mesmo interativa dos parceiros digitais, que com certa justeza e muito orgulho se batizaram internautas [e agora, já de WEB Atores]. 
O magistério da Igreja, com o papa Bento XVI, compreendera já que as novas tecnologias de comunicação interferem nas relações, mudam a maneira de compreender os conteúdos e, portanto, a fé. O papa explicita seu entendimento afirmando que

As novas tecnologias estão a mudar não só o modo de comunicar, mas a própria comunicação em si mesma, podendo-se afirmar que estamos perante uma ampla transformação cultural. Com este modo de difundir informações e conhecimentos, está a nascer uma nova maneira de aprender e pensar, com oportunidades inéditas de estabelecer relações e de construir para a comunhão. (BENTO XVI, 2011, Dia Mundial das Comunicações).

A ampla transformação cultural, e a referência de Bento XVI à mudança da "própria comunicação em si mesma, é encontrada nos resultados e enunciados dos principais pesquisadores, sociólogos e comunicólogos, quando discorrem sobre uma "nova arquitetura do processo informativo", expressão do sociólogo ítalo-brasileiro Massimo Di Felice, quando afirma que "a revolução digital é hoje, a última revolução comunicativa que alterou, pela primeira vez na história da humanidade, a própria arquitetura do processo informativo" (2010). O modo como se realiza essa nova modalidade de transmissão vem sendo estudado e aprofundado por vários pensadores, mas, segundo ainda Di Felice, trata-se da "substituição da forma frontal de repasse das informações (teatro, livro, imprensa, cinema, TV) por aquela reticular, interativa e colaborativa”. O sociólogo explica que, a partir desse contexto, surge "uma nova forma de interação, consequência de uma inovação tecnológica que altera o modo de comunicar e seus significados, estimulando, ao mesmo tempo, inéditas práticas interativas entre nós e as tecnologias de informação" (2011).

\section{A nova "arquitetura" da comunicação}

Sabemos que a partir da Segunda Revolução Industrial as várias derivações inovativas no campo da comunicação com a eletrecidade, o telégrafo, o jornalismo impresso, o rádio, a televisão o entendimento de comunicação como 
técnica é que dominou os estudos e as práticas aplicadas, tanto nos Estados Unidos como na Europa. Nesse contexto, afirma a pesquisadora Lucrécia D’Alessio Ferrara "a essência técnica é entendida como definitiva para estabelecer a origem e identidade da comunicação" (2015, p.30). Assim é que para os principais e conhecidos teóricos Harold Lasswell e Paul Lazarsfeld a comunicação se realiza dentro de um processo que transmite mensagens vindas de um emissor para atingir um receptor. Trata-se de "uma comunicação reduzida à transmissibilidade tendo em vista a consecução de um efeito”.5

Trata-se de uma percepção tradicional utilitária e mecânica, dominante sobretudo no século XX, em que a sociedade viu surgir a massa, "dirigida, no incío, pelo Estado protetor que lhe ditava comportamentos e valores condizentes com a nova condição do homem moderno”. Entretanto, a sociedade logo passou a ser dirigida pelo mercado que, "juntamente com o sistema produtivo, apresentava a mercadoria sob a forma de fetiche e impunha o consumo, no início como valor de uso comercial, mas rapidamente transformado em consumismo como valor de troca” (FERRARA, 2015, p. 35).

Com a evolução das tecnologia de comunicação, novos conceitos foram nascendo e a epistemologia da comunicação é desafiada a rever, também a redefinir conceitos a partir dos novos paradigmas que emergem nos processos comunicativos, no terreno das mídias digitais, que introduzem uma nova forma de relacionar-se, no cotidiano. Neste sentido, “os desafios que decorrem das novas tecnologias impõem mudanças mediativas e interativas de difícil espistemologia da comunicação, mais afeita à mediação que à interação”. E conclui Ferrara que

Exatamente por estar mais afeita à primeira que à segunda, verifica-se que a epistemologia da comunicação tende a analisar a lógica do ciberespaço, utilizando matrizes que foram adequadas aos meios de massa e à comunicação de um significado restrito à mensagem. Mas essa logica é insuficiente para processar a análise do ciberespaço que se constrói de

\footnotetext{
${ }^{5} \mathrm{O}$ modelo comunicativo proposto por Harold Lasswell, em 1948, indica que o ato da comunicação resume-se em responder às seguintes perguntas: quem (emissor), diz o quê (mensagem), através de que canal (meio), para quem (receptor), com que efeito. (WOLF, 1992).
} 
modo contínuo em espaço ambiental qualificado pelas constantes trocas, que nos faz aderir à própria lógica e transforma a comunicação em elemento cultural definidor da atualidade (FERRARA, 2015, p.15).

$\mathrm{Na}$ "nova arquitetura" da comunicação faz-se necessário uma nova teoria social das mídias e perspectivas novas, também, nos estudos da comunicação. Já não se pode pensar as mídias como simples instrumentos ou ferramentas a serem utilizadas. Ao fazer uso dos novos meios, que chamamos também de pós-massivos, passa-se a desenvolver novas formas de interação e surgem novos modos de comunicar alterando o modo de comunicar e seus significados. Pensemos, por exemplo, as redes sociais e os celulares que "são portadores de inovação não somente no âmbito tecnológico, mas também no social, sensorial, político, econômico e cultural" (Di FELICE, 2011).

A transmissão unilinear (ou unidirecional) é substituída, portanto, por aquela reticular, interativa e colaborativa. Na cultura digital, o processo de comunicação passa por matrizes e lógicas diversas daquelas que tivemos até bem pouco tempo. Isto requer mudança de mentalidade para perceber a evolução do processo comunicativo, segundo as épocas, por exemplo, o desdobramento da internet: Web 1.o é a estática, em que as pessoas navegam e consomem informações; a Web 2.0 é a da participação, em que as pessoas usam a Web como base para todo tipo de interação: blogs, fotos,, vídeos, redes sociais, como forma predominante atualmente. Estamos caminhando para a Web 3.0 com a crescente participação de sensores do tipo RFID (RFID (do Radio-Frequency IDentification) e mobile tags (como os Qrcodes, por exemplo). Assim pessoas, animais, objetos, lugares ou "absolutamente qualquer coisa" poderá ser parte da Web. Isto se chama "internet das coisas".

É sobretudo, na Web 2.0 que o então "receptor" se torna "ator", co-criador6. A palavra chave do atual paradigma da comunicação, especialmente com a internet

\footnotetext{
${ }^{6}$ Um dos pesquisadores que, atualmente, vem provocando novas reflexões no campo da sociologia e comunicação é Bruno Latour, com a sociologia do ator-rede, onde os sujeitos são agentes dos próprios processos associativos como a comunicação, por exemplo.
} 
na cultura digital é a interatividade. E esta vem sendo possibilitada, sobretudo, pela internet, viabilizando a intervenção, a participação ativa e mesmo interativa dos parceiros digitais. Segundo Raquel Recuero é preciso considerar que as redes sociais são também “espaços de interação, lugares de fala, construídos pelos atores de forma a expressar elementos de sua personalidade ou individualidade” (RECUERO, 2010, p. 25).

\section{A ação de comunicar o evangelho - a transmissão da fé}

Se a temática da 13 a Assembleia geral Ordinária do Sínodo dos Bispos (2012) foi "A nova evangelização para a transmissão da fé cristã”, é preciso destacar que não faltaram vozes proféticas a oferecer à Igreja reflexão atualizada e carregada de horizontes novos e desafiadores da comunicação como parte integrante e indispensável a ser levada em consideração na transmissão da fé, a ponto de se dizer que não é a fé que está em crise, mas a "transmissão" da fé. Isto tem a ver com as modalidades de transmissão. Entre as vozes proféticas destaca-se a intervenção do então presidente do Pontifício Conselho para as Comunicações Sociais, D. Claudio Maria Celli:

A nova evangelização nos pede para estarmos atentos à "novidade" do contexto cultural no qual somos chamados a anunciar a Boa Nova de Jesus Cristo; mas também à novidade dos métodos [...] Estamos vivendo momentos de profundas mudanças na comunicação. Elas são visíveis no que diz respeito à técnica. Mas na CULTURA são mais significativos ainda. Os novos meios estão mudando radicalmente a cultura na qual vivemos e oferecem novos percursos para condividir o mensagem do evangelho. As novas tecnologias não mudaram só o modo de comunifcar, mas a comunicação em si mesma, criando uma nova infraestrutura cultural que está influenciando o ambiente da comunicação.Não podemos simplesmente fazer aquilo que sempre fazíamos e como fazíamos com as tecnologias. Hoje, mais do que nunca temos necessidade de audácia e sabedoria para evangelizar. Então, primeiramente, fazer atenção que a Boa Nova deve ser proclamada também digitalmente. E o outro desafio é mudar o nosso estilo de comunicação. Devemos ocupar-nos, sobretudo da questão da LINGUAGEM. No fórum digital, há o espontâneo, o interativo e o participativo. (CELI, 2012, Synodus Episcoporum Bollettino, 18/10/2012 - Tradução minha) 
Levando em consideração as transformações da sociedade, sobretudo na área da "revolução das relações" provocadas pelos novos processos comunicativos, irradiados pela cultura digital, damo-nos conta que surge um "novo sujeito" em suas relações e exigências comunicativas. Há uma nova lógica ou seja, uma nova maneira de aprender, de ensinar, como a realidade contextual vem-nos impelindo e, muito sabiamente, o magistério da Igreja vem insistindo em demonstrar, como a mensagem de Bento XVI para o Dia mundial das Comunicações "Verdade, anúncio e autenticidade de vida na era digital" (2011) e, ainda, "Redes sociais: portais de verdade e de fé; novos espaços de evangelização" (2013).

A transmissão da fé, especialmente nos métodos pastorais, deveria estar atenta às novas linguagens que se desenvolvem na comunicação digital, pois elas "determinam, entre outras coisas, uma capacidade mais intuitiva e emotiva do que analítica, orientam para uma diferente organização lógica do pensamento e da relação com a realidade" (BENTO XVI, 2011, b).

Portanto, não se trata simplesmente de adquirir um novo computador. A mudança consiste em uma passagem de uma "idéia" que possuíamos até o momento a respeito do texto, da leitura. Dá-se uma mudança de método, isto é, escrever não é mais oferecer simplesmente uma mensagem pronta que comunica a intenção do autor, mas oferecer material para o trabalho do leitor, que, agora, se transforma em "autor". Muda-se a forma de produzir. Muda, então, a função do chamado receptor. Ele, agora, é web-ator. $\mathrm{Na}$ interatividade, ele constrói, inter+age. É o usuário que se serve, como deseja, dos produtos de consulta; pode escolher segundo os seus gostos e desejos. Assim, especialmente a hipermídia, favorece o desenvolvimento da interatividade de forma extraordinária. Trata-se não apenas de uma"novidade" a mais no mercado e, sim, de novas linguagens que já se encontram, progressivamente, na área da educação. Chegamos a uma etapa na qual cada pessoa se transforma em um "nó" comunicativo coligado a todos os outros. Nessa perspectiva, não se poderá mais viver senão "em rede". 


\section{Conclusão}

Diálogo entre fé e cultura na evangelização do mundo de hoje implica em uma tarefa que vai de uma pastoral aparentemente corriqueira à exigência de transformação de mentalidades e modalidades que ultrapassam o analisar superficialmente a "nova evangelização". Esta deve ocorrer levando em consideração a sociedade complexa do século 21, não só com mudança de paradigmas, mas novos paradigmas, novas sociabilidades, reconfiguradas diariamente pelas novas tecnologias de comunicação, hoje, cultura digital. A “convergência e fusão de horizontes" dos documentos da Igreja Gaudium et Spes, Evangelii Nuntiandi, Evangelii Gaudium, traçam os parâmetros do entendimento do magistério da Igreja para uma evangelização aberta e em diálogo com as culturas para perceber aí as "sementes do Verbo" (PUEBLA, 1979, n. 401, 403, 451).

Na cultura digital, especialmente com a cibercultra, nasce um "novo sujeito", um novo antropológico com quem nos relacionamos. No âmbito da fé, cresce uma nova percepção, nova compreensão da fé e um novo relacionamento com a religião. Tal realidade traz a exigência de novas modalidades para transmitir a fé. E esse processo passa pela nova arquitetura da comunicação, em que acontece uma passagem do paradigma da unilinearidade (unidirecionamento) do transmitir a mensagem para a interatividade. É, sobretudo, nesta nova compreensão do processo comunicativo que acontece a crise na transmissão da fé. "É necessário que nos tornemos ouvintes atentos das linguagens dos homens do nosso tempo, para prestarmos atenção à obra de Deus no mundo”, diz Bento XVI, (2011, b).

Para a comunidade civil, mas sobretudo para a eclesial, apresentam-se desafios que requerem reflexão, pois não se trata apenas de comunicar a mensagem evangélica na linguagem contemporânea, 
mas é preciso ter a coragem de pensar de modo mais profundo, como ocorreu noutras épocas, a relação entre a fé, a vida da Igreja e as transformações que o homem vive. Trata-se do compromisso de ajudar quantos desempenham funções de responsabilidade na Igreja, a ser capazes de compreender, interpretar e falar a «nova linguagem» dos mass media [novas mídias] em função pastoral, em diálogo com o mundo contemporâneo (BENTO XVI, 2011b),

Tendo consciência de que a cultura digital apresenta novos desafios, novas modalidades para transmitir a fé e, portanto, surgem novas questões na linguagem simbólica que fale da transcendência poderíamos nos perguntar: quais são os desafios que o chamado "pensamento digital" apresenta à fé e à teologia? Quais são as interrogações e as exigências? Os ambientes eclesiais, quer na formação acadêmica teológica, quer na prática pastoral, são convidados a superarem a visão puramente instrumental da comunicação e a não correrem o risco de uma defasagem no diálogo entre fé e cultura. A relação entre teologia e comunicação enfrenta uma temática de grande atualidade e, ao mesmo tempo, um forte (e útil!) desafio para a evangelização no nosso tempo.

\section{REFERÊNCIAS}

ABREU, Cristiano Nabuco de; EISENSTEIN, Evelyn: ESTEFENON, Susana G.B. (orgs.). Vivendo esse mundo digital: impactos na saúde, na educação e nos comportamentos sociais. Porto Alegre: Artmed Editora, 2013.

ALTEMEYER JUNIOR, Fernando; BOMBONATTO, Vera I. Teologia e comunicação: corpo, palavra e interfaces cibernéticas (orgs.). São Paulo: Paulinas, 2011.

BENTO XVI. Discurso aos participantes na Assembleia Plenária do Pontifício Conselho para as Comunicações Sociais. 2011b. Disponível em:

$</ /$ w2.vatican.va/content/benedict-xvi/pt/speeches/2011/february/documents/hf_benxvi_spe_20110228_pccs.html -b>. Acesso em 12 de dez. 2016.

BENTO XVI. Novas tecnologias, novas relações:

Promover uma cultura de respeito, de diálogo, de amizade. $43^{\circ}$ Mensagem para o Dia Mundial das Comunicações. 24 de maio de 2009. Disponível em:

<http://w2.vatican.va/content/benedict-xvi/it/messages/communications.index.html>. Acesso em 20 nov.2016. 
BENTO XVI. O sacerdote e a pastoral no mundo digital: os novos media ao serviço da Palavra. $44^{\circ}$ Mensagem para o Dia Mundial das Comunicações. 16 de maio de 2010. Disponível em: <http://w2.vatican.va/content/benedict-

$\mathrm{xvi} / \mathrm{it} / \mathrm{messages} /$ communications.index.html>. Acesso em 26 nov.2016.

BENTO XVI. Verdade, anúncio e autenticidade de vida, na era digital. $45^{\circ}$ Mensagem para o Dia Mundial das Comunicações. 5 de junho de 2011a. Disponível em: <http://w2.vatican.va/content/benedict-xvi/it/messages/communications.index.html>. Acesso em 20 nov.2011.

BENTO XVI. Redes sociais: portais de verdade e de fé: novos espaços de evangelização. $47^{\circ}$ Mensagem para o Dia Mundial das Comunicações. 12 de maio de 2013. Disponível em: <http://w2.vatican.va/content/benedictxvi/it/messages/communications.index.html>. Acesso em 3 de z. 2016.

CAMPBELL, Heidi A. Digital Religion: understanding religious practice in new media worlds. London: Routledge, 2013.

CELLI, Claudio Maria. Synodus Episcoporum Bollettino. Indice degli interventi dei partecipanti. Disponível em:

<http://www.vatican.va/news_services/press/sinodo/documents/bollettino_25_xiiiordinaria-2012/bollettino_25_xiii-ordinaria-2012_index_interventi_xx.html >.Acesso em 12 dez. 2016.

CONCÍlIO VATICANO II. Constituição Pastoral Gaudium et Spes. São Paulo: Paulus, 1997. (Coleção Documentos da Igreja).

CONFERENCIA GERAL DO EPISCOPADO LARINO AMERICANO. Conclusões da Conferência de Puebla. São Paulo: Paulinas, 1979.

CONFERÊNCIA NACIONAL DOS BISPOS DO BRASIL. Diretório de Comunicação da Igreja do Brasil. Brasília: CNBB, 2014.

COULDRY, Nick. Media, Society, World - social theory and digital media practice. 2 ed. Cambridge (UK): Polity Press, 2013.

DI FELICE, Massimo. As redes digitais vistas a partir de uma perspectiva reticular. 2011. Disponível em: <http://www.ihu.unisinos.br/entrevistas/500515-pos-complexidade-asredes-digitais-vistas-a-partir-de-uma-perspectiva-reticular-entrevista-especial-commassimo-di-felice>. Acesso 20 nov. 2016.

DI FELICE, Massimo. FELICE, Massimo di (or). Do Público para as redes: a comunicação digital e as novas formas de participação social. São Caetano do Sul: Difusão Editora, 2008.

FERRARA, Lucrécia D `Alessio. Comunicação, Mediações, Interações. São Paulo: Paulus, 2015.

FRANÇA MIRANDA, Mário de. Evangelizar ou humanizar? 28 jan. 2015. Disponível em: <www.itf.org.br/evangelizar-ou-humanizar.html>. Acesso em: 15 out 2016.

JENKINS, Henry. Cultura da Convergência. São Paulo: Editora Aleph, 2008. 
LEMOS, André. O que é a Cultura Digital, ou Cibercultura? In: SAVAZONI, R.; COHN, S.

Cultura digital.br. Rio de Janeiro : Beco do Azougue, 2009.

LÉVY, Pierre. Cibercultura. São Paulo: Editora 34, 1999.

LIBANIO, João Batista. Exortação Apostólica Evangelii Gaudium do Papa Francisco. Convergencia:Revista Mensal da Conferencia dos Religiosos do Brasil. Rio de Janeiro, v.49, n.469, p. 134-153, 2014.

LOPES, Geraldo. Gaudium et Spes: texto e comentário. São Paulo: Paulinas, 2011.

LORSCHEIDER, Aloisio. Apresentação. In: LOPES, G. P. S.; BOMBONATTO, V. I. (orgs). Concílio Vaticano II: análise e prospectivas. São Paulo: Paulinas, 2004.

MARTINO, L.M.S. Teoria das Mídias Sociais: linguagens, ambientes e redes.

Petrópolis: Vozes, 2014.

O'CONNOR, Martinho J. Instrução Pastoral Communio et Progressio. 23 maio 1971. Disponível em:

<http://www.vatican.va/roman_curia/pontifical_councils/pccs/documents/rc_pc_pccs_ doc_23051971_communio_po.html>.Acesso em: 10 dez. 2016.

PAPA FRANCISCO. Exortação Apostólica Evangelii Gaudium, São Paulo: Paulinas, 2013.

PAULO VI. Discurso por ocasião do encerramento da III Assembleia Geral do Sínodo dos Bispos (26 de outubro de 1974). Roma, AAS 66 (1974), p. 634-635, 637.

PAULO VI. Exortação Apostólica Evangelii Nuntiandi. São Paulo: Paulinas, 1976.

PUNTEL, Joana. Cultura Midiática e Igreja: uma nova ambiência. 2. ed. São Paulo: Paulinas, 2008.

PUNTEL, Joana. Igreja e sociedade - método de trabalho na comunicação. São Paulo: Paulinas, 2015.

RECUERO, Raquel. Redes Sociais na Internet. Porto Alegre: Editora Sulina, 2010.

SPADARO, Antonio. Ciberteologia: pensar o Cristianismo em tempos de rede. São Paulo: Paulinas, 2012.

SPADARO, Antonio. WEB 2.o: redes Sociais. São Paulo: Paulinas, 2014.

SOUZA, N. de. Contexto e desenvolvimento histórico do Concílio Vaticano II. In: LOPES, G. P. S.; BOMBONATTO, V. I. (orgs.). Concílio Vaticano II: análise e prospectivas. São Paulo: Paulinas, 2004.

SILVEIRA, Emerson S. da; AVELLAR, Valter (org.). Espiritualidade e sagrado no mundo cibernético. São Paulo: Loyola, 2014. 
SUESS, Paulo. Catecismo Universal. Proposições do Sínodo sobre nova evangelização e transmissão da fé. IHU, São Leopoldo, RS, 2012. Disponível em:

<http://www.ihuonline.unisinos.br/index.php?option=com_content\&view=article\&id=48 $38 \&$ secao $=412>$. Acesso em 15 out.2014.

THEOBALD, Christoph. A exortação apostólica Evangelii Gaudium. Cadernos Teologia Pública, edição 104, vol.12, 2016. Disponível em: <www.ihu.unisinos.br/556853evangelii-gaudium-e-vaticano-ii-uma-fusao-de-horizontes>. Acesso em 16 nov. 2016.

VALENTINI, Demétrio. Revisitar o Concílio Vaticano II. São Paulo: Paulinas, 2011.

WOLF, Mauro. Teorias da comunicação. Lisboa: Presença, 1992. 